\title{
Expression of Voltage-Gated Chloride Channels in Human Glioma Cells
}

\author{
M. L. Olsen, S. Schade, S. A. Lyons, M. D. Amaral, and H. Sontheimer \\ Department of Neurobiology and Civitan International Research Center, University of Alabama at Birmingham, Birmingham, Alabama 35294
}

\begin{abstract}
Voltage-gated chloride channels have recently been implicated as being important for cell proliferation and invasive cell migration of primary brain tumors cells. In the present study we provide several lines of evidence that glioma $\mathrm{Cl}^{-}$currents are primarily mediated by ClC-2 and ClC-3, two genes that belong to the ClC superfamily. Transcripts for ClC-2 thru ClC-7 were detected in a human glioma cell line by PCR, whereas only ClC-2, ClC-3, and ClC-5 protein could be identified by Western blot. Prominent ClC-2, -3 , and -5 channel expression was also detected in acute patient biopsies from low- and high-grade malignant gliomas. Immunogold electron microscopic studies as well as digital confocal imaging localized a portion of these $\mathrm{ClC}$ channels to the plasma membrane. Whole-cell patch-clamp recordings show the presence of two pharmacologically and biophysically distinct $\mathrm{Cl}^{-}$currents that could be specifically reduced by $48 \mathrm{hr}$ exposure of cells to channel-specific antisense oligonucleotides. ClC-3 antisense selectively and significantly reduced the expression of outwardly rectifying current with pronounced voltage-dependent inactivation. Such currents were sensitive to DIDS (200-500 $\mu \mathrm{m})$ and 5-nitro-2(3-phenylpropylamino) benzoic acid $(165 \mu \mathrm{M})$. ClC-2 antisense significantly reduced expression of inwardly rectifying currents, which were potentiated by hyperpolarizing prepulses and inhibited by $\mathrm{Cd}^{2+}(200-500 \mu \mathrm{m})$. Currents that were mediated by ClC-5 could not be demonstrated. We suggest that ClC-2 and ClC-3 channels are specifically upregulated in glioma membranes and endow glioma cells with an enhanced ability to transport $\mathrm{Cl}^{-}$. This may in turn facilitate rapid changes in cell size and shape as cells divide or invade through tortuous extracellular brain spaces.
\end{abstract}

Key words: ClC channel; brain tumor; patch clamp; antisense knockdown; cell migration; cell proliferation

\section{Introduction}

Most primary brain tumors are derived from glial cells and are collectively referred to as gliomas. This heterogeneous group of tumors includes astrocytomas, glioblastomas, and oligodendrogliomas among others. Their precise lineage relationship to glial cells and the mechanisms underlying their malignant transformation are poorly understood (Linskey, 1997). In addition to their uncontrolled proliferation, glioma cells show an unusual propensity to disperse from the tumor site and invade the healthy brain tissue (Merzak et al., 1994; Merzak and Pilkington, 1997). These characteristics make gliomas elusive targets for surgical management (Kaba and Kyritsis, 1997).

In many aspects, migrating glioma cells mirror the migration of progenitor cells during embryonic brain development (Levison et al., 1993; Amberger et al., 1997; Simpson and Armstrong, 1999), suggesting that they may recapitulate some features of gliogenesis or neurogenesis (Amberger et al., 1997; Noble and Mayer-Pröschel, 1997). Therefore, glioma cells may serve as a model system for studying the mechanisms of cell migration.

Received Dec. 12, 2002; revised April 23, 2003; accepted April 23, 2003.

This work was supported by National Institutes of Health Grant R01-NS36692 and Human Development Grant P3OHD-38985. We thank Dr. Thomas Jentsch for providing the CIC-5 channel-specific antibodies. We also thank Jessy Deshane, Patricia Ritch, Tara Spears, and Ed Phillips for technical assistance.

Correspondence should be addressed to Dr. Harald Sontheimer, 1719 Sixth Avenue South, Civitan International Research Center 545, Birmingham, AL 35294. E-mail: sontheimer@uab.edu.

S. Schade's present address: Transmolecular Inc., 3800 Colonnade Parkway, Suite 240, Birmingham, AL 35243. Copyright $\odot 2003$ Society for Neuroscience $\quad$ 0270-6474/03/235572-11\$15.00/0
Migration and invasion within the spatial constraints of the mature brain require special adaptations for these invading cells. For example, glioma cells appear to undergo shape changes as they squeeze through narrow extracellular brain spaces (Soroceanu et al., 1999; Ransom et al., 2001). Glioma cell shrinkage can be inhibited by $\mathrm{Cl}^{-}$channel blockers that render cells unable to invade, suggesting that this process requires $\mathrm{Cl}^{-}$channelmediated fluid secretion (Soroceanu et al., 1999; Ransom et al., 2001). Hence, $\mathrm{Cl}^{-}$channels may be instrumental in regulating cell volume in the context of glioma cell invasion, a possibly unappreciated aspect of glioma biology. $\mathrm{Cl}^{-}$channels have also been implicated in the growth control of a number of cell types including Schwann cells (Wilson and Chiu, 1993; Pappas and Ritchie, 1998), C6 glioma cells (Rouzaire-Dubois et al., 2000), rat aortic smooth muscle cells (Wang et al., 2002), and mouse liver cells (Wondergem et al., 2001).

Several studies have reported on the expression of $\mathrm{Cl}^{-}$channels in glioma cells, some requiring volume changes for activation (Jackson and Strange, 1993, 1995; Bakhramov et al., 1995; Ullrich and Sontheimer, 1996; Bordey and Sontheimer, 1998; Ullrich et al., 1998; Rouzaire-Dubois et al., 1999; Soroceanu et al., 1999; Ransom et al., 2001); however, the molecular identity of these channels has yet to be elucidated. The most diverse and well studied $\mathrm{Cl}^{-}$channel family currently includes 10 members (ClC0. . . ClC-7, ClC- $\mathrm{Ka}$, and $\mathrm{ClC}-\mathrm{Kb}$ ) that share between 30 and $80 \%$ sequence identity. Five of these channels, $\mathrm{ClC}-2, \mathrm{ClC}-3, \mathrm{ClC}-5$, ClC-6, and ClC-7 have been unequivocally identified in brain 
(Kawasaki et al., 1994; Brandt and Jentsch, 1995), and two, ClC-2 and $\mathrm{ClC}-3$, have been suggested to be involved in cell volume regulation (Coca-Prados et al., 1996; Bond et al., 1998). These channels may therefore be candidates in the search for $\mathrm{Cl}^{-}$channels that facilitate glioma cell invasion.

In the present study we set out to examine the expression and functional activity of endogenous voltage-gated $\mathrm{Cl}^{-}$channels in glioma cells. We demonstrate the expression of ClC-2, ClC-3, and ClC-5 at the mRNA and protein levels. Additionally, whole-cell patch-clamp recordings show two distinct $\mathrm{Cl}^{-}$currents that can be attributed to $\mathrm{ClC}-2$ and $\mathrm{ClC}-3$, respectively, using antisense knock-down strategies.

\section{Materials and Methods}

Cell culture. All experiments were performed on the glioma cell lines D54-MG [glioblastoma multiforme (GBM), World Health Organization (WHO) grade IV], a gift from Dr. D. Bigner (Duke University), U251-MG (GBM; a gift from Dr. Y. Gillespie (University of Alabama at Birmingham). U-138 (GBM), U118 (GBM), U87 (GBM), and STTG-1 (anaplastic astrocytoma, WHO grade III) were obtained from the American Type Tissue Collection (Rockville, MD). Cells were cultured in either DMEM/F12 (Invitrogen, Grand Island, NY) supplemented with 7\% fetal calf serum (FCS) (Hyclone, Logan, UT) or DMEM supplemented with $10 \%$ FCS. No difference was observed between cells cultured in either media.

Electrophysiology. Whole-cell voltage-clamp recordings were obtained via standard methods (Hamill et al., 1981). Patch pipettes were made from thin-walled (outer diameter $1.5 \mathrm{~mm}$, inner diameter $1.12 \mathrm{~mm}$ ) borosilicate glass (TW150F-4; WPI, Sarasota, Fl) and had resistances of 3-5 M $\Omega$. Recordings were made on the stage of an inverted Nikon Diaphot microscope equipped with Hoffman Modulation Contrast Optics. Current recordings were obtained with an Axopatch 200A amplifier (Axon Instruments, Foster City, CA). Current signals were low-pass filtered at $2 \mathrm{kHz}$ and were digitized on-line at $10-20 \mathrm{kHz}$, using a Digidata 1200 digitizing board (Axon Instruments) interfaced with an IBMcompatible computer (Dell XPS R400). Data acquisition and storage were conducted with the use of pClamp 8.2 (Axon Instruments). Cell capacitances and series resistances were measured directly from the amplifier, with the upper limit for series resistance being $10 \mathrm{M} \Omega$, and series resistance compensation was adjusted to $80 \%$ to reduce voltage errors. Liquid junction potentials produced by test solutions were minimized by grounding the recording chamber via an agar salt bridge (4\% agar, 500 $\mathrm{mm} \mathrm{KCl}$ ). Cells were plated on glass coverslips in a 24 -well plate, and recordings were made $24-100 \mathrm{hr}$ after plating. For antisense experiments cells were transfected $48 \mathrm{hr}$ after plating, and recordings were made $48 \mathrm{hr}$ after transfection. Outward currents were elicited by a voltage protocol that stepped the membrane from a holding potential of $-40 \mathrm{mV}$ for 40 $\mathrm{msec}$ and then to voltages ranging from $-60 \mathrm{mV}$ to $120 \mathrm{mV}$ for $180 \mathrm{msec}$. Inward currents were activated from a protocol that stepped from the holding potential of $-40 \mathrm{mV}$ for $40 \mathrm{msec}$ then stepped from $-140 \mathrm{mV}$ to $20 \mathrm{mV}$ for $800 \mathrm{msec}$. Inward currents were activated by holding the cell at $-120 \mathrm{mV}$ for a minimum of $10 \mathrm{sec}$ before the inward current protocol.

Solutions. Unless stated otherwise $\mathrm{KCl}$ pipette solution was used with 2 mM TEA in the extracellular bathing solution to block outward $\mathrm{K}^{+}$currents. The standard $\mathrm{KCl}$ pipette solution contained (in $\mathrm{mm}$ ): $145 \mathrm{KCl}, 1$ $\mathrm{MgCl}_{2}, 10$ EGTA, 10 HEPES sodium salt, $\mathrm{pH}$ adjusted to 7.3 with Trisbase. $\mathrm{CaCl}_{2}(0.2 \mathrm{~mm})$ was added to the pipette solution just before recording, resulting in a free-calcium concentration of $1.9 \mathrm{~nm}$. Cells were perfused continuously at room temperature with a saline solution containing (in mM): $125 \mathrm{NaCl}, 5.0 \mathrm{KCl}, \mathrm{MgSO}_{4}, 1.0 \mathrm{CaCl}_{2}, 1.6 \mathrm{Na}_{2} \mathrm{HPO}_{4}, 0.4$ $\mathrm{Na}_{2} \mathrm{H}_{2} \mathrm{PO}_{4}, 10.5$ glucose, 32.5 HEPES acid, and 2 TEA, $\mathrm{pH}$ adjusted to 7.4 with $\mathrm{NaOH}$. The osmolarity of this solution was $\sim 300$ mOsm. Drugs were added directly to these solutions, and unless stated otherwise all drugs were purchased from Sigma (St. Louis, MO). When $\mathrm{CdCl}_{2}$ was added to the bath solution, phosphates and sulfates were omitted to prevent precipitation of $\mathrm{CdPO}_{4}$ and $\mathrm{CdSO}_{4}$. Similar results were observed when $\mathrm{KCl}$ pipette solution and $2 \mathrm{mM}$ TEA in the bathing solution were replaced with a $\mathrm{CsCl}$ pipette solution $(\mathrm{KCl}$ in pipette replaced with
$145 \mathrm{~mm} \mathrm{CsCl}$ ). For ion replacement studies, $\mathrm{Cl}^{-}$ions in the bathing solution were replaced with an equal amount of the substituting ion.

PCR. Total RNA was extracted from D54-MG cells using Trizol (Invitrogen) using the manufacturer's protocol, treated with DNase (Promega) using the manufacturer's protocol, alcohol extracted with phenol/ chloroform/isoamyl, precipitated, and resuspended in $1 \mathrm{~mm}$ sodium citrate, $\mathrm{pH} 6.4$ (Ambion). Starting with $2 \mu \mathrm{g}$ total D54 RNA as template, cDNA was synthesized using $500 \mathrm{ng}$ random hexamers at $70^{\circ} \mathrm{C}$ for $10 \mathrm{~min}$ before placing the reaction on ice. Tris- $\mathrm{HCl}(14.7 \mathrm{~mm}), \mathrm{pH} 8.3,22 \mathrm{~mm}$ $\mathrm{KCl}, 0.9 \mathrm{~mm} \mathrm{MgCl}, 12 \mathrm{~mm}$ dithiothreitol, $0.6 \mathrm{~mm}$ each dNTP and $12 \mathrm{U}$ Superscript Reverse Transcriptase II (Invitrogen) were added in a final volume of $17 \mu \mathrm{l}$, and the reaction was incubated at $25^{\circ} \mathrm{C}$ for $15 \mathrm{~min}, 42^{\circ} \mathrm{C}$ for $120 \mathrm{~min}$, and $92^{\circ} \mathrm{C}$ for $2 \mathrm{~min}$. For (-) reverse transcriptase (RT) reactions, water was substituted for the Superscript RT II. After the RT reaction was complete, the cDNA was precipitated using $0.1 \mathrm{vol}$ of $5 \mathrm{M}$ ammonium acetate and $2.5 \mathrm{vol}$ of $100 \% \mathrm{EtOH}$ at $-20^{\circ} \mathrm{C}$ for at least $2 \mathrm{hr}$. Precipitated reactions were pelleted by centrifugation and resuspended in $10 \mu \mathrm{l}$ of water. Half of the cDNA was used as template for each PCR reaction. DNA was amplified by adding $100 \mathrm{ng}$ each gene specific primers and Platinum PCR Supermix (Invitrogen: $22 \mathrm{~mm}$ Tris- $\mathrm{HCl}, \mathrm{pH} 8.4,55$ $\mathrm{mm} \mathrm{KCl}, 1.65 \mathrm{~mm} \mathrm{MgCl}_{2}, 220 \mu \mathrm{m}$ each dNTP and $22 \mathrm{U} / \mathrm{ml}$ TaqDNA polymerase with Platinum Taq antibody) for a final reaction volume of $50 \mu \mathrm{l}$. PCR cycling conditions were as follows: an initial denaturation step of $94^{\circ} \mathrm{C}$ for $5 \mathrm{~min}, 94^{\circ} \mathrm{C}$ for $1 \mathrm{~min}$, annealing at $57^{\circ} \mathrm{C}$ for $1 \mathrm{~min}$ for $\mathrm{ClC}-1$, and elongation at $72^{\circ} \mathrm{C}$ for $1 \mathrm{~min}$. A final elongation step of $10 \mathrm{~min}$ at $72^{\circ} \mathrm{C}$ occurred on the last cycle. All PCR reactions were cycled 30 times except for $\mathrm{ClC}-4$, which required 35 cycles. For ClC-2 and $\mathrm{ClC}-4$, the annealing temperature used was $55^{\circ} \mathrm{C}$; for $\mathrm{ClC}-3,-5,-6$, and -7 the temperature was $50^{\circ} \mathrm{C}$. The PCR primers for $\mathrm{ClC}-1, \mathrm{ClC}-2, \mathrm{ClC}-4$, and $\mathrm{ClC}-7$ were created with molecular biology software (Vector NT and GeneTool); ClC-3 and ClC-5 primers have been published previously (Enz et al., 1999) (rat and human are homologous for these primers), and ClC-6 has also been published previously (Eggermont et al., 1997). Primer sets for $\mathrm{ClC}-1, \mathrm{ClC}-2$, and ClC-6 span introns. Primers for all but ClC-1 were produced by Invitrogen; $\mathrm{ClC}-1$ primers were produced by IDT Technologies.

Western blot analysis. Cells were lysed using RIPA buffer [50 mM TrisCl, pH 7.5, $150 \mathrm{~mm} \mathrm{NaCl}, 1 \%$ Nondet P-40 (NP-40), 0.5\% sodium deoxycholate, $1 \%$ SDS] for 30 min supplemented with protease inhibitor mixture obtained from Sigma. Homogenates were centrifuged for $5 \mathrm{~min}$ at 12,000 $\times$ $g$ at $4^{\circ} \mathrm{C}$. Protein quantification was performed on the supernatant using a DC protein assay kit from Bio-Rad (Hercules, CA). Protein was boiled for 5 min in Laemmli-SDS sample buffer containing $600 \mathrm{~mm} \beta$-mercaptoethanol. Equal amounts of protein were loaded into each lane of a 7.5 or $4-20 \%$ gradient precast acrylamide SDS-PAGE gel (Bio-Rad). Proteins were separated at $120 \mathrm{~V}$ constant. Gels were transferred onto polyvinylidene difluoride paper (Millipore, Bedford, MA) at $200 \mathrm{~mA}$ constant for $2 \mathrm{hr}$ at room temperature, and membranes were blocked in blocking buffer (5\% nonfat dried milk, $2 \%$ bovine serum albumin, and $2 \%$ normal goat serum in TBS plus $0.1 \%$ Tween 20 ). Blots were incubated in primary antibody according to manufacturer's instructions. The membranes were then rinsed three times for $10 \mathrm{~min}$ and then incubated with HRP-conjugated secondary antibodies for $90 \mathrm{~min}$. Blots were once again washed three times for $10 \mathrm{~min}$ and developed with enhanced chemiluminesence (Amersham Biosciences, Arlington Heights, IL) on Hyperfilm (Amersham Biosciences). For negative controls blots were stripped and reprobed with the appropriate control peptide incubated with antibody according to manufacturer's instructions. Recent controversy has focused on the specificity of voltage-gated chloride channel antibodies. For that reason we chose to use two sets of antibodies to confirm Western blot and immunocytochemistry results. One set of ClC-2, ClC-3, and $\mathrm{ClC}-5$ polyclonal antibodies was obtained from Alpha Diagnostics (San Antonio, TX). Alternative $\mathrm{ClC}-2$ and $\mathrm{ClC}-3$ antibodies were obtained from Alomone Labs (Jerusalem, Israel), and ClC-5 was a generous gift from Thomas Jentsch (University of Hamburg, Hamburg, Germany). Actin and secondary HRP-conjugated antibodies were purchased from Sigma.

Immunocytochemistry. Cells plated on coverslips (12 mm round; Macalaster Bicknell, New Haven, CT) were washed two times with PBS and fixed with $4 \%$ paraformaldehyde for $15 \mathrm{~min}$. Cells were then washed two more times with PBS and then permeabilized in PBS, $0.3 \%$ Triton X-100, 
and $3 \%$ goat serum [permeabilization buffer (PB)] for 30 min. Primary antibody was diluted in PB and added according to manufacturer's suggestion overnight at $4^{\circ} \mathrm{C}$. The cells were washed three times in PBS before adding an FITC-conjugated goat anti-rabbit secondary antibody (Molecular Probes, Eugene, OR) diluted at 1:500 in PB for $1 \mathrm{hr}$ at room temperature. Cells were then washed two times with PBS, washed once with DAPI $\left(10^{-4} \mathrm{mg} / \mathrm{ml}\right.$; Sigma), and diluted in PBS for $5 \mathrm{~min}$. DAPI was rinsed off with PBS, and then cells were mounted onto clean coverslips with Gel/Mount (Biomedia Corporation, Forest City, CA). Fluorescent images (400 and $1000 \times$ ) were acquired on a Leica DMRB fluorescent microscope (Leica, Heerbrugg, Germany). Digital confocal images (400 nM sections) were acquired with a Zeiss Axiovert 200M (München, Germany).

Immunogold electron microscopy. D54-MG cells were fixed in 4\% paraformaldehyde for $30 \mathrm{~min}$ and in $0.25 \%$ glutaraldehyde for $30 \mathrm{~min}$ at room temperature and then permeabilized with $0.1 \%$ Triton X-100 in PIPES for $45 \mathrm{sec}$ at room temperature. After rinsing and blocking, the cells were incubated with anti-ClC antibodies (Alomone) ClC-2, ClC-3, and Jentsch ClC-5 (1:100) for $4 \mathrm{hr}$ at $4^{\circ} \mathrm{C}$, washed, and incubated with 6 $\mathrm{nm}$ gold-labeled goat anti-rabbit IgG (1:10; Electron Microscopy Sciences) overnight at $4^{\circ} \mathrm{C}$. Cells were rinsed, incubated with $1 \% \mathrm{OsO}_{4}$ for $60 \mathrm{~min}$ at room temperature, dehydrated, and embedded in SPURR's resin (Electron Microscopy Sciences). Ultrathin sections ( $<90 \mathrm{~nm}$ ) obtained on a Reichert Ultracut S (Leica, Heerbrugg, Germany) were contrasted with uranyl acetate and lead citrate and then examined on a JOEL 100 CX electron microscope (Joel, Peabody, MA).

Immunohistochemistry. Human glioma tissues with pathology reports were obtained from three separate sources: The Cooperative Human Network (Eastern and Southern Divisions), the Brain Tumor Tissue Bank (London, UK, and Ontario, Canada), and the University of Alabama at Birmingham Brain Bank (Birmingham, AL). Frozen tissue samples were cryosectioned into $6-8 \mu \mathrm{m}$. The basic procedure for fixing and staining fresh-frozen tissue slices has been described previously (Lyons et al., 2002). Consecutive slices of human tissue were stained with primary antibodies, $\mathrm{ClC}-2$, ClC-3, and $\mathrm{ClC}-5$ (Alomone ClC-2 and ClC-3; Jentsch ClC-5) overnight. After rinsing the next day, an immunoperoxidase staining system, EnVision + Kit (Dako Corporation, Carpenteria, CA) was applied to the tissues for $1 \mathrm{hr}$ at room temperature. Here, an HRP enzyme is conjugated to a secondary rabbit antibody. After rinsing, the binding was detected colorimetrically through reaction with $3^{\prime}, 3^{\prime}$ diaminobenzadine tetrahydrochloride (peroxidase substrate DAB kit, Vector Labs, Burlingame, CA). The slices were rinsed and counterstained with Methyl green (Vector Labs) for $7 \mathrm{~min}$ at $55^{\circ} \mathrm{C}$. The process was completed with three $\mathrm{EtOH}$ rinses and three xylene rinses before slices were permanently mounted under coverslips for microscopic evaluation. Each tissue section was evaluated by comparing $\mathrm{ClC}$ staining with the $\mathrm{ClC}^{-}$controls for a minimum of three times each. Representative fields were chosen for documentation. Staining patterns were compared between consecutive slices as well as with other patient samples from the same tumor type. The staining from each slide was compared with controls and scored by at least two independent evaluators for each patient sample.

Antisense and nonsense oligonucleotide knockdown. Phosphorothiatemodified, $5^{\prime}$ end fluorescein-tagged antisense oligonucleotide primers were purchased from Invitrogen Custom Primers (Rockville, MD). The antisense oligonucleotide primer sequences used were as follows: $\mathrm{ClC} 2$ : 5'-CGCCGCGGCCGCCAT-3'; ClC3: 5'-TCCATTTGTCATTGT-3'. ClC-3 antisense will eliminate both the short and long form of $\mathrm{ClC}-3$ (Shimada et al., 2000). Both sequences used were specific for each protein and not found to be conserved in any other protein. A nonsense primer sequence was constructed from 15 randomized bases (5'CCGTATGACCGCGCC-3') and served as an experimental control. For electrophysiological antisense experiments, tumor cells were plated on glass coverslips in a 24 -well plate at a density of $\sim 15,000$ cells per well and allowed to grow for $2 \mathrm{~d}$ before transfection. Oligonucleotide primers $(0.5-2 \mu \mathrm{g} / \mathrm{ml}$ final concentration) were used in combination with lipofectin. Cells were incubated with DNA/lipofectin for $6 \mathrm{hr}$ with OptiMEM serum-free media (Cancer Center, University of Alabama at Birmingham) according to the manufacturer's instructions and then replaced with normal serum containing media. Antisense-treated cells were selected by their fluorescence. The recording set up was equipped with epifluorescence (Nikon, Garden City, NY). For Western blotting, cells were transfected $24 \mathrm{hr}$ after plating $(25-100 \mu \mathrm{g} / \mathrm{ml})$. Twenty-four hours after transfection serum-containing media was added to the dishes. Cells were harvested and protein lysates were collected $48 \mathrm{hr}$ after transfection.

Statistical analysis. Current-responses to varied voltage steps and ramps were analyzed and measured in Clampfit (Axon Instruments); the resulting raw data were graphed and plotted in Origin 6.0 (MicroCal, Northampton, MA). Unless stated otherwise, all values are reported \pm $\mathrm{SE}$, with $n$ being the number of cells sampled. Two-tailed $t$ tests were performed to evaluate statistical significance, and $p$ values are given in Results (Origin). The constant field potential equation $P_{\mathrm{X}} / P_{\mathrm{Cl}}=[\mathrm{Cl}]_{\mathrm{o}}$ * $\mathrm{e}^{-\left(\Delta E_{\mathrm{rev}}(\mathrm{ZF} / \mathrm{RT})\right.} /[X]_{\mathrm{o}}$ (Hille, 1992) and shifts in reversal potential were used to calculate relative permeability ratios of iodide, bromide, and glutamate to chloride $\left(P_{\mathrm{I}} / P_{\mathrm{Cl}}, P_{\mathrm{Br}} / P_{\mathrm{Cl}}, P_{\mathrm{Gluc}} / P_{\mathrm{Cl}}\right)$. Here, $X$ is the substituting anion, $\Delta E_{\text {rev }}$ is the shift in reversal potential when switching from extracellular chloride $[\mathrm{Cl}]_{\mathrm{o}}$ to the substituting anion $[X]_{\mathrm{o}}$.

\section{Results}

\section{Glioma cells express two biophysically and pharmacologically distinct $\mathrm{Cl}^{-}$currents}

To examine the expression of $\mathrm{Cl}^{-}$channels in glioma cells, we first examined whole-cell currents elicited from cultured D54-MG glioma cells by patch clamp. These recordings were obtained under iso-osmotic conditions, as were all subsequent recordings. To avoid activation of swelling activated currents, we maintained the pipette osmolarity $10 \%$ below that of bath solution. To ensure that we were indeed recording $\mathrm{Cl}^{-}$currents, we initially replaced intracellular $\mathrm{K}^{+}$with $\mathrm{Cs}^{+}$. However, prolonged recordings with $\mathrm{CsCl}$-containing pipette solutions lead to extensive membrane blebbing, a phenomenon that we have not observed in other cells using identical solutions. In turn, blebbing often resulted in the spontaneous activation or enhancement of outward and inward currents. These currents were reminiscent of swelling-activated $\mathrm{Cl}^{-}$currents described previously in these cells (Ransom et al., 2001). To avoid any contamination of our recordings with these spontaneously occurring, swelling activated currents, we subsequently obtained recordings using a $\mathrm{KCl}$ pipette solution while inhibiting $\mathrm{K}^{+}$currents with extracellular TEA ( $2 \mathrm{mM})$, which inhibited outward $\mathrm{K}^{+}$currents as shown previously (Ransom and Sontheimer, 2001). A representative recording (Fig. 1A) demonstrates that outwardly rectifying currents exhibit time-dependent inactivation and particularly that the inactivating current was sensitive to gluconate. Both gluconate and glutamate show decreased permeation and were used to pharmacologically inhibit outward $\mathrm{Cl}^{-}$currents (Ransom et al., 2001). Representative whole-cell traces show that these outward $\mathrm{Cl}^{-}$currents were also sensitive to DIDS $(200-500 \mu \mathrm{M})$ and 5-nitro-2-(3-phenylpropylamino) benzoic acid (NPPB) (165 $\mu \mathrm{M}$ ) (Fig. $1 B, D$ ). Of the mean, normalized peak gluconatesensitive current, $72 \%$ was inhibited by DIDS $(500 \mu \mathrm{M})$, whereas $70 \%$ was inhibited by NPPB $(165 \mu \mathrm{M})$ (Fig. $1 C, E)$. Moreover, the gluconate-sensitive current showed a significant degree of outward rectification and reversed at the chloride equilibrium potential (Fig. 1C,E). The small residual current that remained after gluconate application was sensitive to neither $\mathrm{K}^{+}$nor $\mathrm{Cl}^{-}$channel blockers, and we presume it to be a nonspecific leak conductance.

When we altered the stimulus protocol and applied hyperpolarizing voltage steps ranging from -80 to $-140 \mathrm{mV}$, we observed small inward currents (Fig. 2). It has been demonstrated that inward $\mathrm{Cl}^{-}$currents can be enhanced if voltage steps are preceded by a $30 \mathrm{sec}$ prepulse to $-120 \mathrm{mV}$ (Bond et al., 1998). 
$\mathbf{A}$

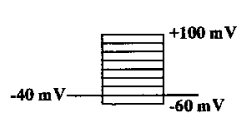

B
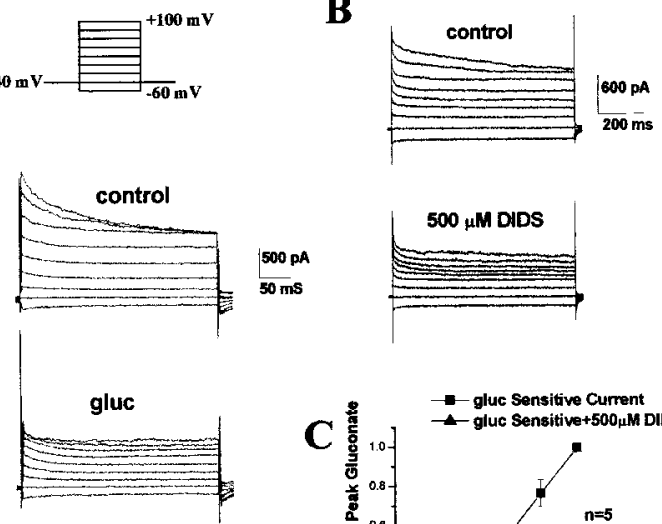

gluc sensitive current

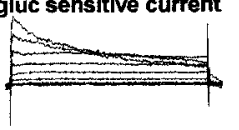

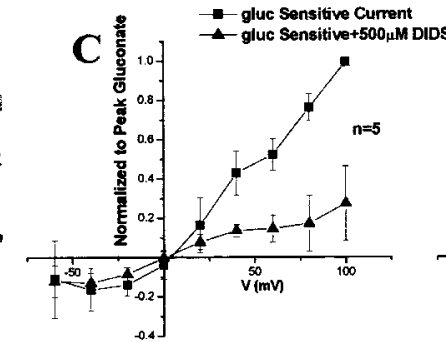

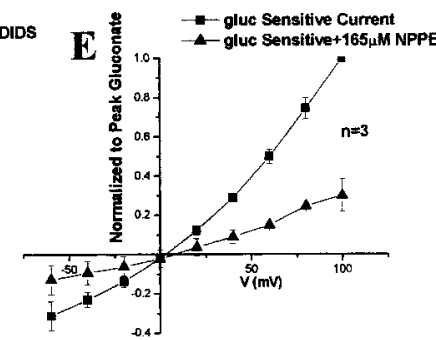

Figure 1. Voltage-dependent outward $\mathrm{Cl}^{-}$currents in human glioma cells. A, Representative examples of whole-cell $\mathrm{Cl}^{-}$ currents that were evoked with voltage steps from -60 to $+100 \mathrm{mV}$ from a holding potential of $-40 \mathrm{mV}$ (in the presence of $2 \mathrm{~mm}$ TEA to block outward potassium currents). Traces demonstrate currents before and after gluconate, and subtraction of the two traces yielded the gluconate-sensitive current. $B$, Whole-cell currents using the same voltage step protocol before and after DIDS $(500 \mu \mathrm{M}) . C, I-V$ plot of peak gluconate-sensitive current before and after DIDS $(500 \mu \mathrm{M})$. D, Whole-cell $\mathrm{Cl}^{-}$currents before and after NPPB $(165 \mu \mathrm{M})$. E, I-V plot of peak gluconate-sensitive currents before and after application of NPPB (165 $\mu \mathrm{M}) . B, D, E, C s C l$ pipette solution.

$\mathbf{A}$
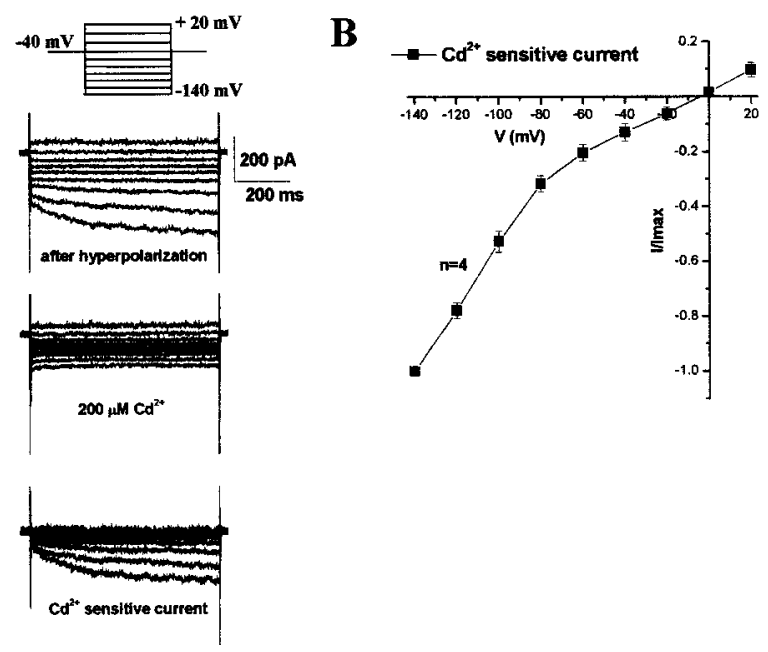

Figure 2. Voltage-dependent inward $\mathrm{Cl}^{-}$currents in human glioma cells. $A$, Inward currents were evoked with voltage steps from -140 to $+20 \mathrm{mV}$ from a holding potential of -40 $\mathrm{mV}$. Cells were hyperpolarized to $-120 \mathrm{mV}$ for a minimum of $20 \mathrm{sec}$ to increase activation of inward current. Representative traces of inward $\mathrm{Cl}^{-}$current before (top) and after $\mathrm{Cd}^{2+}(200$ $\mu \mathrm{m})$ (middle) and the subtracted $C \mathrm{~d}^{2+}$ sensitive current (bottom) are shown. $B, I-V$ plot of $\mathrm{Cd}^{2+}(200 \mu \mathrm{m})$-sensitive $\mathrm{Cl}^{-}$currents evoked from the same voltage step protocol. Currents returned after washout of $\mathrm{Cd}^{2+}$, and removal of the $5 \mathrm{~mm}[\mathrm{~K}]_{0}$ or addition of $200 \mu \mathrm{m} \mathrm{Ba}{ }^{2+}$ had no effect (data not shown).

Indeed, these small inward currents showed increased activation after a hyperpolarizing prepulse. These currents were inwardly rectifying and demonstrated time-dependent activation at voltage steps more negative than $-80 \mathrm{mV}$ (Fig. $2 A, B$ ). As would be expected for inward $\mathrm{Cl}^{-}$currents (outward movement of $\mathrm{Cl}^{-}$), replacement of extracellular $\mathrm{Cl}^{-}$with gluconate did not inhibit these currents, and removal of the extracellular $5 \mathrm{~mm} \mathrm{KCl} \mathrm{had} \mathrm{no}$ effect (data not shown). Pooled data demonstrate sensitivity to $\mathrm{Cd}^{2+}(200 \mu \mathrm{M})$ and marked inward rectification (Fig. 2 B).
Although specific $\mathrm{Cl}^{-}$channel blockers are few, differential sensitivity of $\mathrm{ClC}$ channels to DIDS, 9-AC, NPPB, niflumic acid, tamoxifen, and $\mathrm{Cd}^{2+}$ has been useful for the pharmacological characterization of $\mathrm{ClC}$ $\mathrm{Cl}^{-}$channels. For example, inward $\mathrm{Cl}^{-}$ currents mediated by $\mathrm{ClC}-2$ are typically sensitive to $\mathrm{Cd}^{2+}$ or $\mathrm{Zn}^{2+}$ (Clark et al., 1998; Enz et al., 1999; Nehrke et al., 2002), whereas outward $\mathrm{Cl}^{-}$currents thought to be mediated by ClC-3 are typically inhibited by DIDS or NPPB (Duan et al., 1997; von Weikersthal et al., 1999). Glioma cell outwardly rectifying $\mathrm{Cl}^{-}$currents were consistently found to be sensitive to gluconate, DIDS, and NPPB (Fig. 1B-E). The gluconate-sensitive current (after subtraction) was characterized by pronounced time-dependent inactivation and voltage dependence. By contrast, inward currents were inhibited by $\mathrm{Cd}^{2+}$ (Fig. 2B,C). These $\mathrm{Cd}^{2+}$-sensitive currents showed significant inward rectification and were activated at steps more negative than $-80 \mathrm{mV}$.

Another defining feature of $\mathrm{Cl}^{-}$channels is their permeability to a number of halide and non-halide anions. Indeed, the relative permeability to $\mathrm{I}^{-}, \mathrm{Br}^{-}$, and $\mathrm{F}^{-}$ has been used as a distinguishing feature of $\mathrm{ClC}$ channels and $\mathrm{I}_{\text {CLswell }}$. We therefore examined whether replacement of extracellular $\mathrm{Cl}^{-}$with other anions could sustain these $\mathrm{Cl}^{-}$currents. Indeed, both $\mathrm{I}^{-}$and $\mathrm{Br}^{-}$produced slightly larger outward currents while reducing the inward current; additionally, outward currents were reduced in gluconate (Fig. 3). Relative permeability of ions through channels are typically derived from shifts in tail current reversal potentials; however, $\mathrm{ClC}$ channel gating is coupled to the permeating anion, disallowing this approach (Pusch et al., 1995). If one infers the relative permeability from changes in reversal potential, our reversal potential shifts are suggestive of a permeability sequence of $\mathrm{I}^{-}>\mathrm{Br}^{-}>\mathrm{Cl}^{-}>$glutamate with $P_{\mathrm{I}}{ }^{-}$/ $P_{\mathrm{Cl}}{ }^{-}=1.6, P_{\mathrm{Br}}{ }^{-} / P_{\mathrm{Cl}}{ }^{-}=1.3$, and $P_{\text {glut }}{ }^{-} / P_{\mathrm{Cl}}{ }^{-}=0.24$ (Fig. 3, Table 1).

\section{Glioma cells and acute patient biopsies show expression of ClC-2, -3 , and -5}

We were ultimately interested in determining whether the above described currents could be mediated by known $\mathrm{Cl}^{-}$channels of the $\mathrm{ClC}$ family. In an initial effort to examine this question, we used RT-PCR using specific primers for ClC-1 through ClC-7 (Table 2) and mRNA from D54-MG glioma cells. RT-PCR performed with the specific primers yielded fragments of the predicted molecular weight (Table 2) for ClC-2, $-3,-4,-5,-6$, and -7 , but lacked transcripts for ClC-1 (Fig. 4). The latter has been shown to be specific for muscle (Jentsch et al., 1995). It has been demonstrated previously that there are multiple splice variants of ClC-6. The primer pair that we used had been characterized previously, and RT-PCR analysis with this primer pair yielded fragments at 520 and 350 base pairs. The two bands correspond to the presence or absence of a particular exon (Eggermont et al., 1997).

To examine channel expression at the protein level, we performed Western blots on glioma cell lysates (D54, U251, U158, U87, and STTG1) using antibodies to ClC-2, $-3,-4$, and -5 (Fig. 5). We did not observe any immunoreactivity with ClC-4 (data 


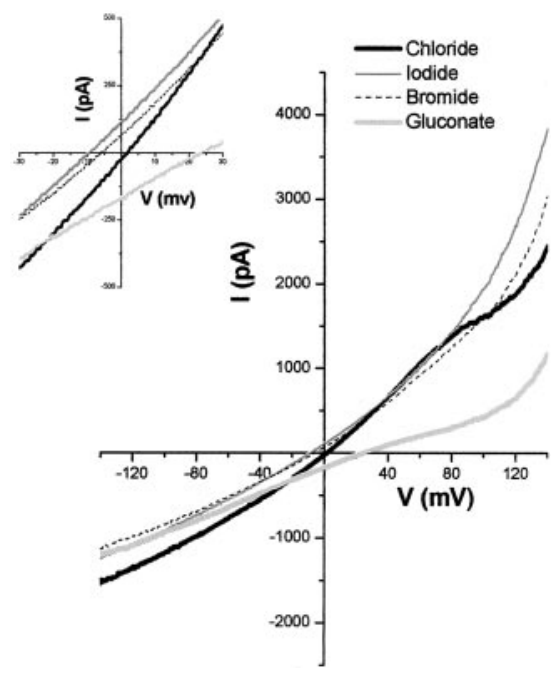

Figure 3. Effects of halide ion replacement on D54 glioma cells. Representative recording of $\mathrm{Cl}^{-}$current from a linear voltage ramp protocol $(-160$ to $+160 \mathrm{mV}$, holding at $-40 \mathrm{mV})$ is shown. Extracellular $\mathrm{Cl}^{-}$(thick black line) in the bath solution was replaced with $130 \mathrm{~mm} \mathrm{Nal}$ (gray line), $\mathrm{NaBr}$ (black dashed line), or Na-gluconate (light gray line). Inset magnifies the region around the reversal potential.

Table 1. Chloride ion replacement shifts the reversal potential in D54 glioma cells

\begin{tabular}{llcl}
\hline Ion & $\begin{array}{l}\text { Number of cells } \\
(n)\end{array}$ & $\begin{array}{l}\text { Shift in reversal p0- } \\
\text { tential }(\mathrm{mV})^{a} \pm \mathrm{SD}\end{array}$ & $P_{\mathrm{x}^{-}} / P_{\mathrm{Cl}^{-}}$ \\
\hline lodide & 9 & $-12.5 \pm 5.3$ & 1.64 \\
Bromide & 8 & $-6.6 \pm 4.7$ & 1.30 \\
Glutamate & 4 & $36.6 \pm 3.9$ & 0.24 \\
\hline
\end{tabular}

Relative to chloride.

Table 2. Primer sets used to RT-PCR CIC channels from D54 glioma cells

\begin{tabular}{|c|c|c|c|}
\hline Gene & Sequence $\left(5^{\prime}-3^{\prime}\right)$ & $\begin{array}{l}\text { Product } \\
\text { length }\end{array}$ & Accession number \\
\hline $\mathrm{CIC}-1$ & $\begin{array}{l}\text { se GCATCTGTGCTGCTGTCCTC } \\
\text { as GACACCGAGCATGACTTGGC }\end{array}$ & $410 \mathrm{bp}$ & NM_000083 \\
\hline $\mathrm{CIC}-2$ & $\begin{array}{l}\text { se GGGGGCCCAGTGTCACCAGGAAC } \\
\text { as CGGGGGAGGCCATGACGGGAGTG }\end{array}$ & $556 \mathrm{bp}$ & NM_004366 \\
\hline $\mathrm{ClC}-3$ & $\begin{array}{l}\text { se CCTCTTTCCAAAGTATAGCAC } \\
\text { as TTACTGGCATTCATGTCATTTC }\end{array}$ & 552 bp & AF172729 \\
\hline CIC-4 & $\begin{array}{l}\text { se GCGGGCAGGATGGTGGGAATTG } \\
\text { as GCGCCGCAGCTTCAGGGGATGT }\end{array}$ & $650 \mathrm{bp}$ & AF170492 \\
\hline $\mathrm{CIC}-5$ & $\begin{array}{l}\text { se GGAACATCCTGTGCCACTG } \\
\text { as AATCACAGAGCTTGGAGGAG }\end{array}$ & $543 \mathrm{bp}$ & X91906 \\
\hline $\mathrm{CIC}-6$ & $\begin{array}{l}\text { se GTTTAACTTCCCCTATTTCC } \\
\text { as GCATTCTCCTAACACCATCG }\end{array}$ & $\begin{array}{l}519 \mathrm{bp} \\
353 \mathrm{bp}\end{array}$ & NM_001286 \\
\hline $\mathrm{CIC}-7$ & $\begin{array}{l}\text { se GGGCGTGGTGGGCGGTGTG } \\
\text { as CGCCCCCGTGAGGTAGGACAGG }\end{array}$ & 472 bp & Z67743 \\
\hline
\end{tabular}

not shown); however, we consistently saw bands corresponding to $\mathrm{ClC}-2,-3$, and -5 . Because there remains significant controversy concerning the specificity of these antibodies (Stobrawa et al., 2001), we went to great efforts to confirm their specificity and hence the validity of our results. Specifically, we used at least two different sources for each antibody (Alomone: $\mathrm{ClC}-2$, and -3; T. Jentsch: ClC-5; Alpha Diagnostics: ClC-2,-3,-5). Representative blots with six tumor cell lines that were probed with antibodies obtained from Alpha Diagnostics are shown in Figure 5A. For comparison, two glioma cells lines, D54 and STTG-1, were probed with Alomone's $\mathrm{ClC}-2$ and $\mathrm{ClC}-3$ and Jentsch ClC-5 antibodies (Fig. 5B). Note that similar bands were observed in both

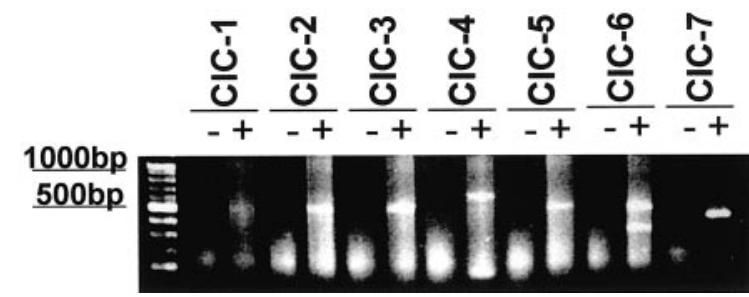

Figure 4. RT-PCR of CIC-1 through CIC-7 in D54 glioma cells. Lane 1 is a 100 bp marker (Invitrogen). Lanes denoted with + are RT-PCR reactions with primers for the designated CIC channel. Lanes denoted with - are identical reactions with water substituted for reverse transcriptase. Using D54-MG total RNA as a template, only the muscle-specific CIC-1 primers did not yield a product. $\mathrm{CIC}-2$ through CIC-7 mRNA was present in D54-MG cells as judged by amplification of the expected size PCR products using gene-specific primers.
A
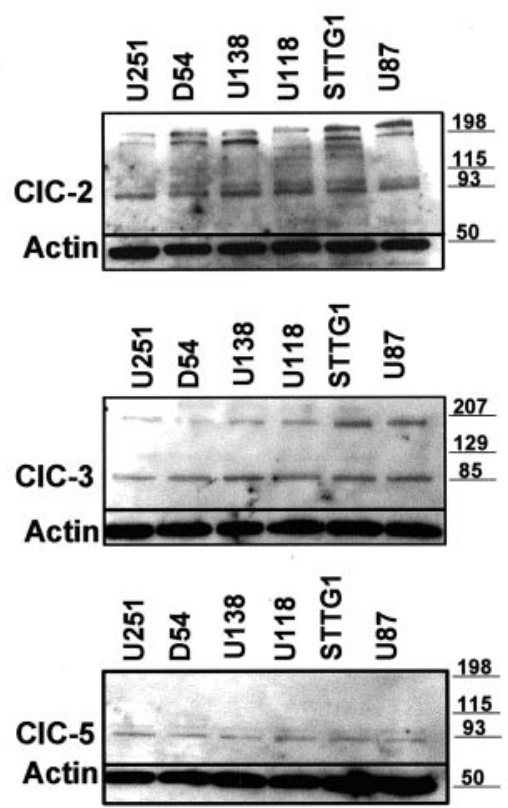

B
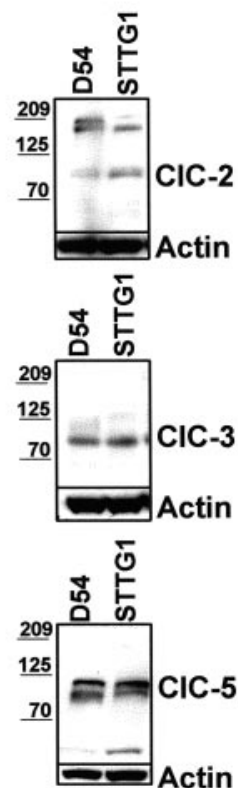

Figure 5. Western blot analysis demonstrating expression of $\mathrm{ClC}-2$, $\mathrm{ClC}-3$, and $\mathrm{CIC}-5$ in the human glioma cell lines U251, D54, U138, U118, STTG1, and U87. A, Top, Alpha Diagnostics CIC-2 antibody recognizes a doublet at $\sim 90 \mathrm{kDa}$ and several bands at a higher molecular weight, possibly multimers of CIC-2. A, Middle, Alpha Diagnostics CIC-3 antibody recognizes a prominent band at $\sim 85 \mathrm{kDa}$ and a much lighter band $\sim 15 \mathrm{kDa}$ higher. A, Bottom, Alpha Diagnostics $\mathrm{ClC}-5$ antibody recognizes a prominent band at $\sim 90 \mathrm{kd}$ and a lighter band at a slightly higher molecular weight. $B$ demonstrates similar results with Alomone's $\mathrm{CIC}-2$ and $\mathrm{CIC}-3$ antibodies and Jentsch CIC-5 antibody. All blots either were probed with actin (Sigma) as a loading control with the designated antibody or they were stripped and reprobed.

sets of blots at the appropriate molecular weights. To confirm the specificity of each antibody and as a negative control, the blots were probed with the antibodies preabsorbed with the matching peptide. Under these conditions all bands seen were essentially eliminated (data not shown).

To illustrate the distribution of $\mathrm{ClC}-2$, $\mathrm{ClC}-3$, and $\mathrm{ClC}-5$ in human glioma cells, we used immunocytochemistry with FITCconjugated secondary antibodies. Distinct localization was observed for each, with differential staining of the cytoplasm versus cell surface (Fig. 6). Figure 6, $A$ and $B$, demonstrates $400 \times$ and $1000 \times$ images, respectively. The images in Figure $6 C$ are digital confocal images. All images shown were probed with Alpha Diagnostics antibodies; however, similar results were obtained with the alternate set of antibodies. Interestingly, all three $\mathrm{ClC}$ channels (ClC-2, -3 , and -5) appear to associate prominently with 

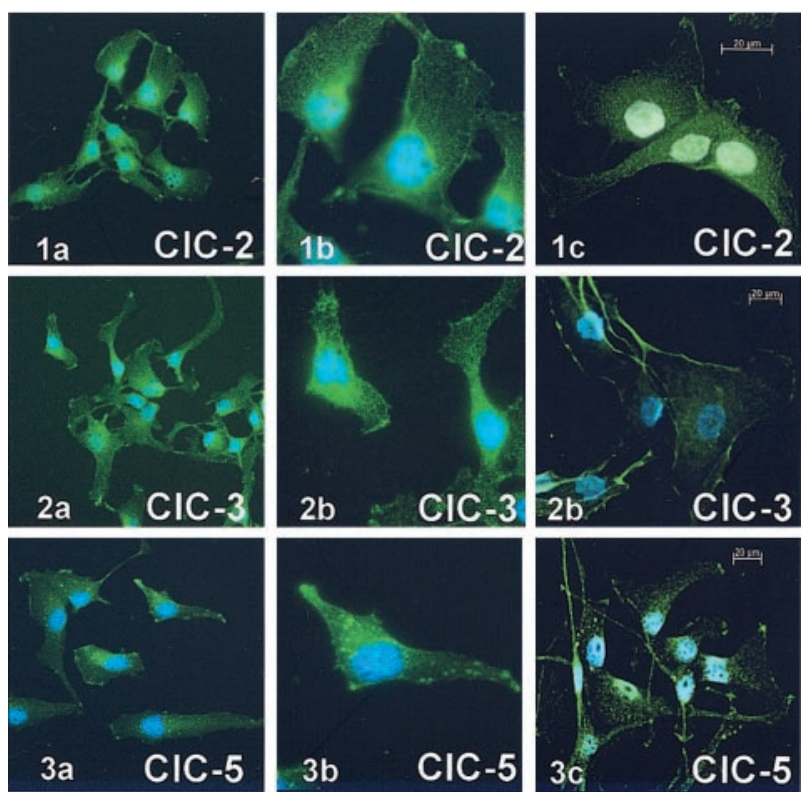

Figure 6. Immunoreactivity for $\mathrm{CIC}-2$, $\mathrm{ClC}-3$, and $\mathrm{ClC}-5$ demonstrates intracellular and plasma membrane labeling of D54 glioma cells (Alpha Diagnostics). Left panels are $400 \times$ images; middle panels are $1000 \times$ images. Right panels demonstrate $400 \mathrm{~nm}$ sections of digital confocal images. Similar results were observed with Alomone $\mathrm{CIC}-2$ and $\mathrm{CIC}-3$ and Jentsch CIC -5 antibodies.

lamellipodia at the leading edges of the cells, and overall they appear in clusters on the membrane. In addition, both Alpha Diagnostics and Jentsch ClC-5 antibody recognized large vesicular type structures in the cell cytoplasm.

To further confirm the surface expression of these channels, we obtained immunogold electron microscopy (EM) images from D54 glioma cells in which ClC-2, -3 , and -5 were each conjugated to $6 \mathrm{~nm}$ gold particles. As is demonstrated in Figure $7 A-C$ (white arrows), immunoreactivity for each channel was found in surface clusters.

Because the above studies were performed on cultured cells, we sought to confirm these findings by examining $\mathrm{ClC}$ expression in acute biopsies from patients with glioblastoma multiforme and pilocytic astrocytoma. Several such biopsies were examined, and a representative example of each tumor type is illustrated in Figure 8. Paraffin sections of these biopsies were stained with $\mathrm{ClC}$ antibodies, followed by secondary antibodies detected with DAB (a brown reaction product). These studies show prominent expression of $\mathrm{ClC}-2,-3$, and -5 and by and large confirmed our findings in cultured cells. Taken together, our biochemical and immmunohistochemical studies suggest that ClC-2, -3 , and -5 are expressed in glioma cells in vivo and that, at least in isolated glioma cells, a significant percentage of these channels is localized in the plasma membrane.

\section{Antisense studies suggest that glioma $\mathrm{Cl}^{-}$currents are mediated in part by $\mathrm{ClC}-2$ and $\mathrm{ClC}-3$}

We next sought to determine whether any of the currents observed in glioma cells (Figs. 1-3) could be attributed to defined $\mathrm{ClC}$ channels. Because of the current profiles, we hypothesized that the inactivating, outwardly rectifying currents were attributable to $\mathrm{ClC}-3$, whereas the activating, inwardly rectifying currents were attributable to $\mathrm{ClC}-2$. The lack of specific $\mathrm{Cl}^{-}$channel blockers led us to use antisense knockdown techniques to investigate our hypothesis. We used specific antisense primers for
ClC-2 and ClC-3 (sequences given in Materials and Methods). D54-MG cells were recorded $48 \mathrm{hr}$ after transfection with fluorescently tagged antisense and nonsense oligonucleotides. Current densities of successfully transfected cells (identified by their fluorescence) were analyzed. Representative traces for ClC-3 antisense knockdown demonstrated a significant reduction in whole-cell currents (Fig. 9A). Mean current densities of nonsense- and antisense-treated cells exhibited significant reductions in whole-cell currents at potentials that typically show the greatest activation ( $50 \%$ at the peak current, $p<0.01)$ (Fig. 9B). The specificity of the ClC-3 antisense oligonucleotides is demonstrated in Figure $9 C$. When an equal amount of protein is loaded (as evidenced by actin loading control), ClC-3 protein was dramatically reduced when $\mathrm{D} 54$ cells were treated with the $\mathrm{ClC}-3$ antisense oligonucleotides.

Cells treated with antisense to $\mathrm{ClC}-2$ demonstrated a marked reduction in inward current (Fig. 10 A). Once again, peak current densities at hyperpolarized potentials were significantly reduced by $60 \%(p<0.03)$ (Fig. $10 \mathrm{~B})$. Interestingly, treatment with ClC-2 antisense oligonucleotides also increased the input resistance of these cells $(1239 \pm 270 \mathrm{M} \Omega)$, with average values for nonsense-treated cells of $485 \pm 99 \mathrm{M} \Omega$ and ClC-3 antisensetreated cells $=598 \pm 101 \mathrm{M} \Omega(n=14$ control, $n=10 \mathrm{ClC}-2 ; p<$ 0.01 , relative to nonsense). Consistent with this change, the leak current in these cells appeared to be smaller, suggesting that ClC-2 contributed to the resting conductance. Alternatively, secondary effects caused by antisense treatment may have affected other membrane properties such as trafficking of other channels to the membrane that are typically open at rest. We do not believe this is the result of nonspecific antisense toxicity, because this would cause a decrease in the mean input resistance, making the cell appear leaky, which is the opposite of what we observed. Antisense specificity for ClC-2 is demonstrated by Western blot in Figure $10 \mathrm{D}$. Only cells treated with antisense oligonucleotides for $\mathrm{ClC}-2$ demonstrate a decrease in the amount of $\mathrm{ClC}-2$ protein.

The reduction in whole-cell currents of cells treated with antisense suggested that both $\mathrm{ClC}-2$ and $\mathrm{ClC}-3$ contribute to distinctly different $\mathrm{Cl}^{-}$currents in D54 glioma cells.

Of note, antisense knockdown specifically interrupts the synthesis of new protein but has no affect on existing protein. Hence the effective depletion of functional channels in the membrane depends primarily on the turnover of these proteins. We currently do not know the turnover time for $\mathrm{ClC}$ channels. However, for voltage-gated $\mathrm{Na}^{+}$channels, a half-life of $26 \mathrm{hr}$ in neuroblastoma cells (Waechter et al., 1983) and $2 \mathrm{~d}$ in rat neurons has been reported (Schmidt and Catterall, 1986). Therefore, complete elimination of channel synthesis would only reduce currents by $50 \%$ every $24-48 \mathrm{hr}$, a value that compares favorably with the effect that we observed in our knockdown experiments.

\section{Discussion}

In the present study we demonstrate the presence of a subset of $\mathrm{ClC}$ genes and their proteins in cultured glioma cells. Specifically, we provide evidence for expression of $\mathrm{ClC}-2,-3$, and -5 protein in glioma cell membranes, often associated with lamellipodia. Importantly, the same complement of channels was observed in acute biopsies from patients who had these tumors removed surgically. We overcame the absence of specific pharmacological drugs for $\mathrm{ClC}$ channels subtypes through the use of an antisense knockdown strategy. These studies suggest that $\mathrm{Cd}^{2+}$-sensitive inward $\mathrm{Cl}^{-}$currents can be reduced with $\mathrm{ClC}-2$ antisense, 
whereas outwardly rectifying, DIDSsensitive currents are selectively reduced after ClC-3 knockdown.

$\mathrm{Cl}^{-}$channels have been referred to as "the problem children of ion channels" (Clapham, 2001), and the field harbors considerable controversies. This is primarily attributable to the absence of specific pharmacological inhibitors for $\mathrm{Cl}^{-}$ channels and great deal of concerns surrounding the specificity of antibodies for their detection of channel proteins. Single-channel properties that might clarify some of theses issues are scarce because of the small conductances of these channels. Also, essentially all of our current knowledge on $\mathrm{ClC}$ channels is derived from their recombinant expression and characterization in Xenopus oocytes. To add to the controversy, it has been suggested that overexpression of $\mathrm{ClC}$ channels causes upregulation of endogenous Xenopus channels (for review, see Schmieder et al., 2002). In light of these issues, we went to great lengths to establish the specificity of our reagents and approach. For example, the use of multiple commercial and noncommercial antibodies for Western blots and immunocytochemistry yielded convergent results. In addition, Western blotting demonstrates the specificity of our knockdown strategy by only reducing either $\mathrm{ClC}-2$ or $\mathrm{ClC}-3$ protein levels.

\section{Biophysical and pharmacological properties of $\mathrm{ClC}$ currents in glioma cells}

The signature features reported for recombinant ClC-2 currents are (1) inward rectification, (2) time-dependent activation, (3) potentiation by negative holding potentials, and (4) sensitivity to $\mathrm{Cd}^{2+}$ and $\mathrm{Zn}^{2+}$ (Clark et al., 1998; Enz et al., 1999; Nehrke et al., 2002). Our pharmacological and biophysical characterization of inwardly rectifying $\mathrm{Cl}^{-}$currents in glioma cells is consistent with these reported features for ClC-2. Our knockdown studies selectively reduced these inward currents by $60 \%$, demonstrating that these currents were mediated at least partially by ClC-2. Interestingly, ClC-2 knockdown was associated with a marked increase in the input resistance of the cells. This suggests that $\mathrm{ClC}-2$ may contribute to the high $\mathrm{Cl}^{-}$permeability in these cells. Indeed, we and others have shown that such a high resting $\mathrm{Cl}^{-}$conductance is common for proliferating glial cells that have undergone neoplastic transformation or in response to injury (gliosis) (for review, Walz, 2002). We did not see a comparable change in the resting $\mathrm{Cl}^{-}$conductance after the knockdown of ClC-3.

Currents thought to be mediated by $\mathrm{ClC}-3$ have been described as outwardly rectifying and DIDS and NPPB sensitive, and they often show pronounced voltage-dependent inactivation (Duan et al., 1997; von Weikersthal et al., 1999). Consistent with these features, glioma cells expressed outwardly rectifying DIDSand NPPB-sensitive currents. After antisense treatment, outward peak currents were reduced by $50 \%$, with the voltage-dependent inactivating current component nearly eliminated. The fact that these currents were selectively reduced after antisense treatment with ClC-3-specific oligonucleotides strongly suggests that they were mediated at least in part by ClC-3. The strategy pursued in our studies was very similar to that used in several recent publications demonstrating the selective loss of outwardly rectifying currents after ClC-3 antisense treatment in HeLa, Xenopus oocytes, and bovine epithelial cells (Wang et al., 2000; Hermoso et al., 2002).

Although we were able to detect ClC-5 at both the mRNA and protein levels, we lacked conclusive biophysical evidence for functional channels in glioma cells. As reported previously, ClC-5 gives rise to outwardly rectifying currents that are unaffected by all known $\mathrm{Cl}^{-}$channel inhibitors (Mo et al., 1999). When we recorded in the simultaneous presence of DIDS or NPPB and TEA, we occasionally recorded a small, time- and voltage-dependent outward current that may be attributed to ClC-5 (data not shown). The low probability of seeing these currents in glioma cells $(<10 \%)$ made it impossible to study them by antisense knockdown approaches. ClC-5 has been reported to be found in endocytotic vesicles (Gunther et al., 1998), yet when expressed in oocytes, $\mathrm{ClC}-5$ mediated plasma membrane cur- 

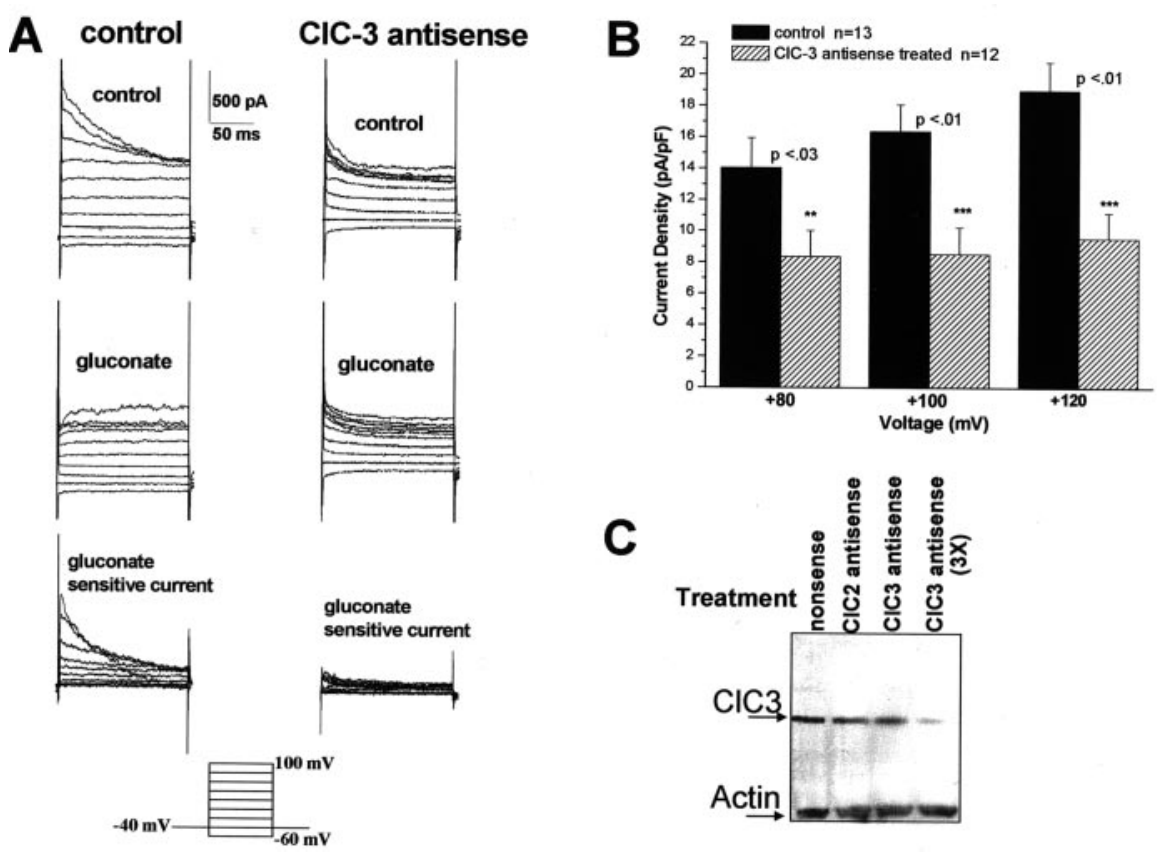

Figure 9. CIC-3 antisense oligonucleotides inhibit whole-cell outward $\mathrm{Cl}^{-}$currents in D54 glioma cells. A, Whole-cell outward currents from a representative control (nonsense- or CIC-2 antisense-treated cell) and CIC-3 antisense-treated cell before and after $\mathrm{Na}$-gluconate bath solution and the subtracted gluconate-sensitive current. Currents elicited by voltage step protocol are shown in the inset. $B$, Antisense treatment significantly reduced whole-cell outward $\mathrm{Cl}^{-}$currents at peak voltages: $+80,40 \% ;+100 \mathrm{mV}$, $48 \% ;+120 \mathrm{mV}, 50 \%$. Interestingly, the current that remained appeared to be the leak current that was not sensitive to gluconate ( $n=$ number of cells examined). C, Western blot analysis demonstrates the specificity of the $\mathrm{CIC}-3$ antisense oligonucleotides (lane 1, nonsense-treated cells; Iane 2, CIC-2 antisense-treated cells; lane 3, CIC-3 antisense-treated cells; lane 4, CIC-3 antisense-treated cells with a threefold higher concentration of DNA). Of note, for electrophysiology experiments $\mathrm{CIC}-3$ was used at a three- to fourfold higher concentration than CIC-2 (see Materials and Methods).

rents (Friedrich et al., 1999). Our studies show some localization on the cell surface of glioma cells by immunocytochemistry and immunogold EM. The functional significance, if any, of such membrane-associated $\mathrm{ClC}-5$ in glioma cells is unclear and warrants further study.

We routinely used ion replacements to verify that the recorded currents were indeed carried by $\mathrm{Cl}^{-}$. We always observed a potentiation of outward currents by $\mathrm{Br}^{-}$and $\mathrm{I}^{-}$as was reported for recombinant ClC-3 (Duan et al., 1997), and currents were always greatly diminished in gluconate or glutamate. A significant, albeit controversial body of literature exists on the relative permeability of ClC channels to other anions (for review, see Fahlke, 2001). However, because ion permeation and gating are believed to be coupled processes in these channels, it is impossible to accurately determine the relative permeability (Pusch et al., 1995). Moreover, we were recording endogenous currents, in which more than one channel population contributed to the overall $\mathrm{Cl}^{-}$current. Hence, we are not comfortable drawing any conclusions from our ion replacement studies; instead, we are using them as a means to isolate true $\mathrm{Cl}^{-}$ currents.

\section{Localization of $\mathrm{ClC}$ channels}

ClC-2 appears to be a ubiquitous $\mathrm{Cl}^{-}$channel that has been identified previously on the plasma membrane of many cell types. In the nervous system, $\mathrm{ClC}-2$ channels are found on the end feet of astrocytes and on the cell body, axons, and dendrites of hippocampal neurons, where they have been implicated in chloride homeostasis and $\mathrm{Cl}^{-}$movements associated with GABAergic synaptic transmission (Sik et al., 2000). Although ClC-3 and ClC-5 have been identified in brain (Steinmeyer et al., 1995; von
Weikersthal et al., 1999; Stobrawa et al., 2001), recent papers suggest that both ClC-3 and ClC-5 are almost exclusively channels associated with intracellular vesicles (Gunther et al., 1998; Stobrawa et al., 2001). We therefore felt compelled to study the precise localization of $\mathrm{ClC}$ channels in glioma cells in greater detail. Our immunocytochemical and confocal studies localize these channels in lamellipodia, and our immunogold EM studies unequivocally identify clusters of $\mathrm{ClC}-2$, ClC-3, and ClC-5 immunoreactivity in the cell membrane. It is possible that membrane expression of $\mathrm{ClC}$ channels is found primarily in dividing, highly motile cells and hence absent from normal brain cells. As discussed further below, $\mathrm{Cl}^{-}$ channel function has been implicated in both cell proliferation and cell migration.

\section{Functional implications}

Chloride channels have been implicated in a multitude of cellular functions that include osmoregulation, salt secretion, cell migration, and cell proliferation (for review, see Jentsch et al., 2002). Of these functions, the role of $\mathrm{Cl}^{-}$channels in the regulation of cell volume in response to a changing osmotic environment is the most well studied. However, unequivocal molecular identification of the underlying $\mathrm{Cl}^{-}$channels has been a tedious task. A significant number of reports attribute cell volume regulation to a ubiquitous but elusive $\mathrm{Cl}^{-}$channel named $\mathrm{I}_{\text {Clswell }}$ (Nilius et al., 1998). Nevertheless, some studies provide compelling evidence for a partial role of $\mathrm{ClC}-2$ and $\mathrm{ClC}-3$ in volume regulation. For example, knockdown of endogenous ClC-3 in HeLa cells (Hermoso et al., 2002), bovine epithelial cells (Wang et al., 2000), or oocytes impairs regulatory volume decrease. Inhibition of ClC-2 by functional blocking antibodies impairs volume regulation in rat hepatoma cells (Roman et al., 2001), knockdown of ClC- 3 by antisense oligonucleotides eliminates swelling-activated currents (von Weikersthal et al., 1999), and mutation of a single amino acid (serine 51) alters volume activation of ClC-3 (Duan et al., 1999). However, transgenic knock-out mice for either ClC-2 or ClC-3 have not been able to detect any defects in cell volume regulation (Stobrawa et al., 2001; Arreola et al., 2002; Nehrke et al., 2002). This apparent discrepancy may be attributable to a compensatory mechanism and must be reconciled by future studies.

For other aspects of biology, $\mathrm{Cl}^{-}$channel function has been less well studied, yet a few studies have implicated $\mathrm{Cl}^{-}$channels in cell shape changes that may occur in conjunction with cell division or cell migration. For example, it has been demonstrated that cell division is associated with a transient increase in cell volume (Premack and Gardner, 1991; Garber and Cahalan, 1997) and can be inhibited by $\mathrm{Cl}^{-}$channel blockers (Voets et al., 1995; Phipps et al., 1996; Schlichter et al., 1996). Increased $\mathrm{Cl}^{-}$channel activity has been shown to coincide with entry into the cell cycle in human cervical cancer cells (Shen et al., 2000), and $\mathrm{Cl}^{-}$channel blockers have been shown to modulate Schwann cell proliferation (Wilson and Chiu, 1993; Pappas and Ritchie, 1998). Sim- 
ilarly, the proliferation of C6 glioma cells, rat aortic smooth muscle cells, and mouse liver cells is inhibited after ClC-3 knockdown (Rouzaire-Dubois et al., 2000; Wondergem et al., 2001; Wang et al., 2002). These studies suggest that the inability to regulate cell volume may be the underlying mechanism that leads to impaired cell proliferation. Indeed, in astrocytes it has been demonstrated that cell swelling activates mitogen-activated kinases that in turn modulate astrocytic $\mathrm{Cl}^{-}$channels (Crépel et al., 1998). The most direct link to date of a molecularly identified $\mathrm{Cl}^{-}$channel and cell proliferation-maturation comes from two recent studies in Caenorhabditis elegans. Here the activity of CLH-3, an ortholog of $\mathrm{ClC}-2$, is required to induce oocyte maturation (Rutledge et al., 2001). The activation of CLH-3 channels occurs by serine-threonine dephosphorylation via a type 1 protein phosphatase (Rutledge et al., 2002), a feature that was also been demonstrated for rat ClC-2. These examples demonstrate intriguing functional interactions of $\mathrm{Cl}^{-}$channels with the cell cycle machinery.

Other evidence suggests that $\mathrm{Cl}^{-}$channels may also serve important functions in the context of cell migration. In rat astrocytes, changes in cell morphology are sufficient to induce $\mathrm{Cl}^{-}$currents (Lascola and Kraig, 1996), with cytoskeletal actin being responsible for gating of $\mathrm{Cl}^{-}$channels (Lascola et al., 1998). Calcium levels, which increase in migratory cells (Pastan et al., 1992; Komuro and Rakic, 1998), have been shown to affect the localization of voltage-gated $\mathrm{Cl}^{-}$channels (Lascola et al., 1998; Huang et al., 2001). Moreover, the translocation of cell processes has been suggested to require local volume increases in those parts of the cell that are in the active process of locomotion (Ehrengruber et al., 1996; Voura et al., 1998). More specifically, it is believed that $\mathrm{Cl}^{-}$and $\mathrm{K}^{+}$enter at the leading edge of a lamellipodia, leading to local swelling that is obligatory for the translocation of this cellular process (Schneider et al., 2000). A similar requirement for $\mathrm{Cl}^{-}$channel-mediated $\mathrm{Cl}^{-}$efflux has been shown for migrating glioma cells. These cells have a significant resting $\mathrm{Cl}^{-}$conductance that is obligatory for migration (Ransom et al., 2001), because pharmacological inhibition of $\mathrm{Cl}^{-}$channels by either $\mathrm{Cd}^{2+}$ or NPPB impaired glioma migration (Soroceanu et al., 1999; Ransom et al., 2001). Although indirect, these findings are consistent with a contribution of $\mathrm{Cd}^{2+}$-sensitive $\mathrm{ClC}-2$ channels and possibly NPPBsensitive ClC-3 channels to glioma cell migration. It appears that these $\mathrm{Cl}^{-}$channels allow the secretion of $\mathrm{Cl}^{-}$along with obligated water to accomplish cell shrinkage, which in turn facilitates glioma cell invasion into narrow extracellular spaces. Other immature neuronal or glial precursor cells or stem cells in the mature brain may similarly invoke $\mathrm{Cl}^{-}$channel function during cell migration. Clearly, further studies are necessary to elucidate the role of $\mathrm{Cl}^{-}$ channels in cell migration-invasion in general, and the specific contribution of $\mathrm{ClC}$ channels in this context warrants further study.

\section{References}

Amberger VR, Avellana-Adalid V, Hensel T, Baron-Van Evercooren A, Schwab ME (1997) Oligodendrocyte-type 2 astrocyte progenitors use a metalloendoprotease to spread and migrate on CNS myelin. Eur J Neurosci 9:151-162.

Arreola J, Begenisich T, Nehrke K, Nguyen HV, Park K, Richardson L, Yang B, Schutte BC, Lamb FS, Melvin JE (2002) Secretion and cell volume regulation by salivary acinar cells from mice lacking expression of the $\mathrm{Clcn} 3$ $\mathrm{Cl}(-)$ channel gene. J Physiol (Lond) 545:1-16.

Bakhramov A, Fenech C, Bolton TB (1995) Chloride current activated by hypotonicity in cultured human astrocytoma cells. Exp Physiol 80:373-389.

Bond TD, Ambikapathy S, Mohammad S, Valverde MA (1998) Osmosensitive $\mathrm{Cl}-$ currents and their relevance to regulatory volume decrease in human intestinal t84 cells: outwardly vs. inwardly rectifying currents. J Physiol (Lond) 511:45-54.

Bordey A, Sontheimer H (1998) Electrophysiological properties of human astrocytic tumor cells in situ: enigma of spiking glial cells. J Neurophysiol 79:2782-2793.

Brandt S, Jentsch TJ (1995) Clc-6 and Clc-7 are two novel broadly expressed members of the Clc chloride channel family. FEBS Lett 377:15-20.

Clapham D (2001) How to lose your hippocampus by working on chloride channels. Neuron 29:1-3.

Clark S, Jordt SE, Jentsch TJ, Mathie A (1998) Characterization of the hyperpolarization-activated chloride current in dissociated rat sympathetic neurons. J Physiol (Lond) 506:665-678.

Coca-Prados M, Sanchez-Torres J, Peterson-Yantorno K, Civan MM (1996) Association of $\mathrm{Clc}-3$ channel with $\mathrm{Cl}-$ transport by human nonpigmented ciliary epithelial cells. J Membr Biol 150:197-208.

Crépel V, Panenka W, Kelly MEM, MacVicar BA (1998) Mitogen-activated protein and tyrosine kinases in the activation of astrocyte volumeactivated chloride current. J Neurosci 18:1196-1206.

Duan D, Winter C, Cowley S, Hume JR, Horowitz B (1997) Molecular identification of a volume-regulated chloride channel. Nature 390:417-421.

Duan D, Cowley S, Horowitz B, Hume JR (1999) A serine residue in Clc-3 
links phosphorylation-dephosphorylation to chloride channel regulation by cell volume. J Gen Physiol 113:57-70.

Eggermont J, Buyse G, Voets T, Tytgat J, De Smedt H, Droogmans G, Nilius B (1997) Alternative splicing of ClC-6 (a member of the CIC chloridechannel family) transcripts generates three truncated isoforms one of which, ClC-6c, is kidney-specific. Biochem J 325:269-276.

Ehrengruber MU, Deranleau DA, Coates TD (1996) Shape oscillations of human neutrophil leukocytes: characterization and relationship to cell motility. J Exp Biol 199:741-747.

Enz R, Ross BJ, Cutting GR (1999) Expression of the voltage-gated chloride channel ClC-2 in rod bipolar cells of the rat retina. J Neurosci 19:9841-9847.

Fahlke C (2001) Ion permeation and selectivity in ClC-type chloride channels. Am J Physiol Renal Physiol 280:F748-F757.

Friedrich T, Breiderhoff T, Jentsch TJ (1999) Mutational analysis demonstrates that $\mathrm{ClC}-4$ and $\mathrm{ClC}-5$ directly mediate plasma membrane currents. J Biol Chem 274:896-902.

Garber SS, Cahalan MD (1997) Volume-regulated anion channels and the control of a simple cell behavior. Cell Physiol Biochem 7:229-241.

Gunther W, Luchow A, Cluzeaud F, Vandewalle A, Jentsch TJ (1998) Clc-5, the chloride channel mutated in Dent's disease, colocalizes with the proton pump in endocytotically active kidney cells. Proc Natl Acad Sci USA 95:8075-8080.

Hamill OP, Marty A, Neher E, Sakmann B, Sigworth FJ (1981) Improved patch-clamp techniques for high resolution current recording from cells and cell free membrane patches. Pflügers Arch 391:85-100.

Hermoso M, Satterwhite CM, Andrade YN, Hidalgo J, Wilson SM, Horowitz B, Hume JR (2002) ClC-3 is a fundamental molecular component of volumesensitive outwardly rectifying $\mathrm{Cl}-$ channels and volume regulation in HeLa cells and Xenopus laevis oocytes. J Biol Chem 277:40066-40074.

Hille B (1992) Ionic channels in excitable membranes. Sunderland, MA: Sinauer.

Huang P, Liu J, Di A, Robinson NC, Musch MW, Kaetzel MA, Nelson DJ (2001) Regulation of human ClC-3 channels by multifunctional $\mathrm{Ca}^{2+} /$ calmodulin-dependent protein kinase. J Biol Chem 276:20093-20100.

Jackson PS, Strange K (1993) Volume-sensitive anion channels mediate swelling-activated inositol and taurine efflux. Am J Physiol 265:489-500.

Jackson PS, Strange K (1995) Characterization of the voltage-dependent properties of a volume-sensitive anion conductance. J Gen Physiol 105:661-676.

Jentsch TJ, Günther W, Pusch M, Schwappach B (1995) Properties of voltage-gated chloride channels of the ClC gene family. J Physiol (Lond) [Suppl] 482:19S-25S.

Jentsch TJ, Stein V, Weinreich F, Zdebik AA (2002) Molecular structure and physiological function of chloride channels. Physiol Rev 82:503-568.

Kaba SE, Kyritsis AP (1997) Recognition and management of gliomas. Drugs 53:235-244.

Kawasaki M, Uchida S, Monkawa T, Miyawaki A, Mikoshiba K, Marumo F, Sasaki S (1994) Cloning and expression of a protein kinase C-regulated chloride channel abundantly expressed in rat brain neuronal cells. Neuron 12:597-604.

Komuro H, Rakic P (1998) Orchestration of neuronal migration by activity of ion channels, neurotransmitter receptors, and intracellular $\mathrm{Ca}^{2+}$ fluctuations. J Neurobiol 37:110-130.

Lascola CD, Kraig RP (1996) Whole-cell chloride currents in rat astrocytes accompany changes in cell morphology. J Neurosci 16:2532-2545.

Lascola CD, Nelson DJ, Kraig RP (1998) Cytoskeletal actin gates a $\mathrm{Cl}^{-}$ channel in neocortical astrocytes. J Neurosci 18:1679-1692.

Levison SW, Chuang C, Abramson BJ, Goldman JE (1993) The migrational patterns and developmental fates of glial precursors in the rat subventricular zone are temporally regulated. Development 119:611-622.

Linskey ME (1997) Glial ontogeny and glial neoplasia: the search for closure. J Neurooncol 34:5-22.

Lyons SA, O’Neal J, Sontheimer H (2002) Chlorotoxin, a scorpion-derived peptide, specifically binds to gliomas and tumors of neuroectodermal origin. Glia 39:162-173.

Merzak A, Pilkington GJ (1997) Molecular and cellular pathology of intrinsic brain tumours. Cancer Metastasis Rev 16:155-177.

Merzak A, McCrea S, Koocheckpour S, Pilkington GJ (1994) Control of human glioma cell growth, migration and invasion in vitro by transforming growth factor $\beta_{1}$. Br J Cancer 70:199-203.

Mo L, Hellmich HL, Fong P, Wood T, Embesi J, Wills NK (1999) Compar- ison of amphibian and human ClC-5: similarity of functional properties and inhibition by external pH. J Membr Biol 168:253-264.

Nehrke K, Arreola J, Nguyen HV, Pilato J, Richardson L, Okunade G, Baggs R, Shull GE, Melvin JE (2002) Loss of hyperpolarization-activated Cl(-) current in salivary acinar cells from Clcn2 knockout mice. J Biol Chem 277:23604-23611.

Nilius B, Prenen J, Voets T, Eggermont J, Droogmans G (1998) Activation of volume-regulated chloride currents by reduction of intracellular ionic strength in bovine endothelial cells. J Physiol (Lond) 506:353-361.

Noble M, Mayer-Pröschel M (1997) Growth factors, glia and gliomas. J Neurooncol 35:193-209.

Pappas CA, Ritchie JM (1998) Effect of specific ion channel blockers on cultured Schwann cell proliferation. Glia 22:113-120.

Pastan I, Chaudhary V, Fitzgerald DJ (1992) Recombinant toxins as novel therapeutic agents. Annu Rev Biochem 61:331-354.

Phipps DJ, Branch DR, Schlichter LC (1996) Chloride-channel block inhibits T lymphocyte activation and signaling. Cell Signal 8:141-149.

Premack BA, Gardner P (1991) Role of ion channels in lymphocytes. J Clin Immunol 11:225-238.

Pusch M, Ludewig U, Rehfeldt A, Jentsch TJ (1995) Gating of the voltagedependent chloride channel CIC-O by the permeant anion. Nature 373:527-531.

Ransom CB, Sontheimer H (2001) BK channels in human glioma cells. J Neurophysiol 85:790-803.

Ransom CB, O’Neal JT, Sontheimer H (2001) Volume-activated chloride currents contribute to the resting conductance and invasive migration of human glioma cells. J Neurosci 21:7674-7683.

Roman RM, Smith RL, Feranchak AP, Clayton GH, Doctor RB, Fitz JG (2001) ClC-2 chloride channels contribute to HTC cell volume homeostasis. Am J Physiol Gastrointest Liver Physiol 280:G344-G353.

Rouzaire-Dubois B, Bostel S, Dubois JM (1999) Evidence for several mechanisms of volume regulation in neuroblastoma $\mathrm{x}$ glioma hybrid NG108-15 cells. Neuroscience 88:307-317.

Rouzaire-Dubois B, Milandri JB, Bostel S, Dubois JM (2000) Control of cell proliferation by cell volume alterations in rat C6 glioma cells. Pflügers Arch 440:881-888.

Rutledge E, Bianchi L, Christensen M, Boehmer C, Morrison R, Broslat A, Beld AM, George AL, Greenstein D, Strange K (2001) CLH-3, a ClC-2 anion channel ortholog activated during meiotic maturation in C. elegans oocytes. Curr Biol 11:161-170.

Rutledge E, Denton J, Strange K (2002) Cell cycle- and swelling-induced activation of a Caenorhabditis elegans $\mathrm{ClC}$ channel is mediated by CeGLC7alpha/beta phosphatases. J Cell Biol 158:435-444.

Schlichter LC, Sakellaropoulos G, Ballyk B, Pennefather PS, Phipps DJ (1996) Properties of $\mathrm{K}^{+}$and $\mathrm{Cl}^{-}$channels and their involvement in proliferation of rat microglial cells. Glia 17:225-236.

Schmidt JW, Catterall WH (1986) Biosynthesis and processing of the a-subunit of the voltage-sensitive sodium channel in rat brain neurons. Cell 46:437-445.

Schmieder S, Lindenthal S, Ehrenfeld J (2002) Cloning and characterisation of amphibian ClC-3 and ClC-5 chloride channels. Biochim Biophys Acta 1566:55-66.

Schneider SW, Pagel P, Rotsch C, Danker T, Oberleithner H, Radmacher M, Schwab A (2000) Volume dynamics in migrating epithelial cells measured with atomic force microscopy. Pflügers Arch 439:297-303.

Shen MR, Droogmans G, Eggermont J, Voets T, Ellory JC, Nilius B (2000) Differential expression of volume-regulated anion channels during cell cycle progression of human cervical cancer cells. J Physiol (Lond) 529:385-394.

Shimada K, Li X, Xu G, Nowak DE, Showalter LA, Weinman SA (2000) Expression and canalicular localization of two isoforms of the Clc- 3 chloride channel from rat hepatocytes. Am J Physiol Gastrointest Liver Physiol 279:G268-276.

Sik A, Smith RL, Freund TF (2000) Distribution of chloride channel-2immunoreactive neuronal and astrocytic processes in the hippocampus. Neuroscience 101:51-65.

Simpson PB, Armstrong RC (1999) Intracellular signals and cytoskeletal elements involved in oligodendrocyte progenitor migration. Glia 26:22-35.

Soroceanu L, Manning TJ Jr, Sontheimer H (1999) Modulation of glioma cell migration and invasion using $\mathrm{Cl}^{-}$and $\mathrm{K}^{+}$ion channel blockers. J Neurosci 19:5942-5954.

Steinmeyer K, Schwappach B, Bens M, Vandewalle A, Jentsch TJ (1995) 
Cloning and functional expression of rat Clc-5, a chloride channel related to kidney disease. J Biol Chem 270:31172-31177.

Stobrawa SM, Breiderhoff T, Takamori S, Engel D, Schweizer M, Zdebik AA, Bosl MR, Ruether K, Jahn H, Draguhn A, Jahn R, Jentsch TJ (2001) Disruption of ClC-3, a chloride channel expressed on synaptic vesicles, leads to a loss of the hippocampus. Neuron 29:185-196.

Ullrich N, Sontheimer H (1996) Biophysical and pharmacological characterization of chloride currents in human astrocytoma cells. Am J Physiol 270:C1511-C1521.

Ullrich N, Bordey A, Gillespie GY, Sontheimer H (1998) Expression of voltage-activated chloride currents in acute slices of human gliomas. Neuroscience 83:1161-1173.

Voets T, Szucs G, Droogmans G, Nilius B (1995) Blockers of volumeactivated $\mathrm{Cl}-$ currents inhibit endothelial cell proliferation. Pflügers Arch 431:132-134.

von Weikersthal SF, Barrand MA, Hladky SB (1999) Functional and molecular characterization of a volume-sensitive chloride current in rat brain endothelial cells. J Physiol (Lond) 516:75-84.

Voura EB, Sandig M, Kalnins VI, Siu C (1998) Cell shape changes and cy- toskeleton reorganization during transendothelial migration of human melanoma cells. Cell Tissue Res 293:375-387.

Waechter CJ, Schmidt JW, Catterall WA (1983) Glycosylation is required for maintenance of functional sodium channels in neuroblastoma cells. J Biol Chem 258:5117-5123.

Walz W (2002) Chloride/anion channels in glial cell membranes. Glia 40:1-10.

Wang GL, Wang XR, Lin MJ, He H, Lan XJ, Guan YY (2002) Deficiency in ClC-3 chloride channels prevents rat aortic smooth muscle cell proliferation. Circ Res 91:E28-E32.

Wang L, Chen L, Jacob TJ (2000) The role of Clc-3 in volume-activated chloride currents and volume regulation in bovine epithelial cells demonstrated by antisense inhibition. J Physiol (Lond) 524:63-75.

Wilson GF, Chiu SY (1993) Mitogenic factors regulate ion channels in Schwann cells cultured from newborn rat sciatic nerve. J Physiol (Lond) 470:501-520.

Wondergem R, Gong W, Monen SH, Dooley SN, Gonce JL, Conner TD, Houser M, Ecay TW, Ferslew KE (2001) Blocking swelling-activated chloride current inhibits mouse liver cell proliferation. J Physiol (Lond) 532:3-72. 